\title{
Antibacterial Activity of White and Blue Wild Myrtle Parts Extracts Against Staphylococcus aureus and Staphylococcus epidermidis
}

\section{Mayson Layqa, A. A. Nizam and I. Alqadi}

Plant Biology Department, Faculty of Sciences, Damascus University, Damascus, Syria.

\begin{abstract}
A
NTIBACTERIAL activity of acetone, ethanol and water extracts of parts of the indigenous in Syria wild myrtle Myrtus communis L., (root, stem, leaves, fruits) with different concentrations $(25,50,75$, $100 \%$ ) was carried out against gram-positive bacteria growth which isolated and identified from the pathogenic specimens of Damascus Children's Hospital, Bacterial laboratory, using agar well diffusion method on Mueller - Hinton medium. The results showed the effect of Myrtle extracts concentration on bacterial growth, increasing concentration causes rise inhibition diameter of bacterial growth.

The effect of Myrtle acetone extracts was more effective against Staphylococcus epidermidis and Staphylococcus aureus, and the best effect of parts extracts of both plants was better on the two types of bacteria as follows: leaves> fruits> stem> roots, increasing concentration succeeded to increase inhibition zone of bacterial growth, and results showed that acetone extracts induced pronounced effectiveness of the largest in the two types of bacteria, followed by ethanolic then aqueous extracts, inhibition effective against $S$. epidermidis was more much than $S$. aureus. Generally, the effect of blue myrtle parts extracts were more effective on bacteria than white type. This study also confirmed the antimicrobial potential of investigated plants and their usefulness in treatment of resistance gram-positive microorganisms.
\end{abstract}

Keywords: Wild blue and white myrtle, Bacteria, Acetone, Ethanol, Water extracts, Root, Stem, Leaves, Fruit.

Infectious diseases are the leading cause of death worldwide. Increased antibiotic resistance has become a global concern, this increase has been attributed to indiscriminate use of broad-spectrum antibiotics, immunosuppressive agents, intravenous catheters, organ transplantation and ongoing epidermidis of human immunodeficiency virus (HIV) infections (Parekh \& Chanda, 2007 and Vaghasiya \& Chanda, 2007). Because antimicrobial resistant microorganisms fail to respond to therapy, infections due these microorganisms result in prolonged illness, longer stays in hospitals and a greater risk of death (Gupta et al., 2005 and Sandhu \&Heinrich, 2005). Infectious diseases represent an important cause of morbidity and mortality among the general population, particularly in developing countries. Therefore, pharmaceutical companies have been motivated 
to develop new antimicrobial drugs in recent years (Nascimento et al., 2000; Sakagami \& Kajimura, 2002 and Maneemegalai \& Naveen, 2010).

According to WHO more than $80 \%$ of the World's Population rely on traditional medicine for their primary health care needs (Ammara et al., 2009). Medicinal plants are known to produce certain bioactive molecules which are responsible for their antimicrobial properties (Rios \& Recio, 2005 and Kuete, 2010). Medicines obtained from plants are relatively safer than synthetic alternative (Iwu et al., 1999 and Idu et al., 2007). The substances that can inhibit pathogens and have little toxicity to host cells are considered as candidates for developing new antimicrobial drugs. Among the various materials to replace antibiotics, products of plant origin have recently gotten a special place (Harikrishnan et al., 2003 and Immanuel et al., 2004).

Aromatic plants have capacity to synthesize, accumulate and emit volatile substances that may act as aroma and flavor molecules due to interaction with living organisms. These low molecular weight substances derived from fatty acid, amino acid and carbohydrate pools constitute a heterogeneous group of molecules and cyclic structures bearing various functional groups (e.g. alcohols, aldehydes, ketones, esters and ethers) and also nitrogen and sulfur. Many plants belong to Myrtaceae family are reported to have antibacterial or antifungal activities (Mansouri et al., 2001 and Shahidi-Bonjar, 2004-a,b).

Myrtle(Myrtus communis L.; Myrtaceae) is a shrub, evergreen and aromatic herb with numerous stems and branches, growing spontaneously throughout the Mediterranean region of Syria in natural forests, and a typical annual shrub of the other Mediterranean countries such as Greece, Turkey, Tunisia, Algeria, Morocco and Italy and Iran.

Myrtle species are known to be very rich in aromatic substances due to the presence of high essential oil content in its leaf, flower, and fruit glands and play an important role for their antimicrobial, tonic and balsamic properties (De Laurentis et al., 2005).

Extensive researches have been conducted to evaluate the antimicrobial effect of the essential oils and extracts which show the strength and ability to inhibit the growth of a wide range of pathogenic microorganisms as Staphylococcus aureus and Bacillus cereus (Shahidi-Bonjar, 2004-a), E. coli (Bouzouita et al., 2003 and Shahidi-Bonjar, 2004-b), Lactobacillus plantarum (Bouzouita et al., 2003), Listeria monocytogenes and Pseudomonas aeruginosa, (Shanmugavelu et al., 2006 and Amensour et al., 2010), Klebsiella and Shigella (Shanmugavelu et al., 2006), though its antimicrobial effect against some strains of bacteria such as $E$. coli has been rejected in some studies (Amensour et al., 2010).

Some gram-negative bacteria such as E. coli and Pseudomonas aeruginosa and some gram-positive bacteria such as Staphylococcus aureus have specific

Egypt. J. Microbiol. 50 (2015) 
characteristics as far as bacterial infections (Rahimi \& Athari, 2008 and Sharifi et al., 2010).

Staphylococci are among the most robust microbes that infect humans, if the barrier is breached by trauma, surgery or other means (needles, etc.) the organisms gain access to the underlying tissue and creates a local abscess.

Staphylococcus aureus is a major human pathogen, implicated in both hospital and community acquired infections. In addition to the increase of antibiotic resistance that often limits therapeutic options, pathogenic bacteria can adapt and survive in specific micro environments that are also associated with therapeutic failure and recurrence or persistence of infection. It can contaminate any site of the human body by intrapersonal transfer by aerosol and by direct contact. Among them, biofilms play a significant role in persistent infections formed on the surface of implanted medical devices and in deep tissues (Chambers, 2001; Ziel, 2004; Archer et al., 2011 and Barretti et al., 2012). Biofilms protect bacteria from host defense and antibiotics, allowing them to remain dormant for long periods within the host, and represent a reservoir for resistance development and for bacterial dissemination within the body (Otto, 2008).

Staphylococcus epidermidis is a part of the microflora found in normal human skin and mucous membranes at the patients (Wieser \& Busse, 2000) and which is one of the most bacteria common in the hospitals (Hope et al., 1989 and Haussen \& Rand, 1998). It is responsible for the death by inhibiting immunity at the hospitals (Malicova et al., 2007).

Furthermore, one of the characteristics of Staphylococci are their high resistance to antimicrobial agents, The bacteria have been found to be associated with foreign bodies, such as prosthetic heart valves, cerebrospinal fluid shunts, and orthopedic prostheses, as well as intravascular, urinary and dialysis catheters (Walton et al., 2004).

Accordingly, given the importance of medicinal plants in the traditional medicine and very few side effects of these medicines on human and also due to the changes in the form of the resistance of pathogenic bacteria which require monitoring of antibacterial effects substances in periodic intervals, the antimicrobial effects of aqueous-, alcoholic- and acetone extracts of Myrtle parts (fruits, leaves, stems, and roots) against the pathogenic bacteria (Staphylococcus aureus and S. epidermidis) have been evaluated in this study.

\section{Material and Methods}

\section{Plant Materials}

The parts of two kinds of myrtle commonly used in folk medicine were collected during spring and autumn season from Forollok forest (Latakia, Syria) and they were air dried in the shade after washing. Specimens of the plants were 
deposited in the herbarium of the Plant Biology Department, Damascus University, Syria.

\section{Preparation of extracts}

Each dry powdered plant material (20 g) was extracted using $100 \mathrm{ml}$ of ethanol or acetone (Merck, Darmstadt) for $24 \mathrm{~h}$ by using Soxhlet equipment (Dugler \& and Gonuz; 2004 and Amensour et al., 2010). The extracts were filtered using Whatman filter paper \#1 and the filtrates were then evaporated under reduced pressure using a rotary evaporator at $45^{\circ} \mathrm{C}$ (for acetonlic extract) and $55^{\circ} \mathrm{C}$. (for ethanolic extract). Dried extracts were stored in labeled sterile screw capped bottles at $-20^{\circ} \mathrm{C}$.

Each dry powdered plant material $(10 \mathrm{~g})$ was extracted using $100 \mathrm{ml}$ distillated water for 7 days by using shaker at $25^{\circ} \mathrm{C}$. The extract was filtered using Whatman filter paper \#1 and the filtrate was then sterilized using bacterial filter membrane $0.2 \mu \mathrm{l}$, then evaporated under reduced pressure by using a rotary evaporator. Dried extract was stored in labeled sterile screw capped bottle at $20^{\circ} \mathrm{C}$ (Al-Salammi, 2006).

\section{Bacterial strains}

Bacteria were prepared from the samples of patients referred to Children hospital of Damascus University after doing specialized microbiologic tests for confirming the presence of microorganisms. Cultures were identified by Phoenix ${ }^{\mathrm{TM}}$ Automated Microbiology System (BD- Biosciences, Sprarks, MD) at microbiological laboratory in the hospital (Horstkotte et al., 2004), Antibacterial activity was applied on Staphylococcus aureus, Staphylococcus epidermidis.

\section{Determining bioactivity of the extracts}

Conducted bacterial culture for the extracts on the Mueller Hinton agar diffusion method in agar wells (Andrews, 2003 and Rojas et al., 2003), for the cultivation of bacteria $24 \mathrm{~h}$ old and transferred to physiological solutions concentration of 0.5 MacFarland. After that was making 3-4 wells (diameter $6 \mathrm{~mm}$ ) in the petri dish, and adding plant extracts at a rate of $20 \mu \mathrm{l}$ (Rojas et al., 2003) to each well, by three replicates, and then left in the fridge for an hour of being impregnated with the active ingredient, and incubated dishes at $37{ }^{\circ} \mathrm{C}$ for $24 \mathrm{~h}$, then measured diameter halo of inhibition and taking the average of the replicates. To determine the effectiveness, witness sample containing DMSO only the size of the store in the user extracts itself.

\section{Statistical analysis}

Results were presented as average \pm standard deviation of nine replicates, and tested the meaning differences between the averages way ANOVA analysis of variance depending on the Tukey test in multiple comparisons with the level of significance $\mathrm{p}<0.05$ depending on the statistical program STATISTICA ver.8 (Statsoft 2007). 


\section{Results and Discussion}

Antibacterial activity of extracts of myrtle fruits

The average diameter of inhibition zone of the acetone extract with $100 \%$ concentration of the fruits of the white myrtle reached at least to $22 \mathrm{~mm}$ against Staphylococcus aureus and S. epidermidis (Table 1). Antibacterial activity of the extract of the fruits of blue myrtle was higher than in white and they both induced the effect on $S$. aureus higher than in the other type. The influence of the acetone extract of myrtle fruits was higher than the ethanolic extract (Table 1). The aqueous extract of the fruits of blue myrtle with concentration of $100 \%$ was more effective in the inhibition of the two types of bacteria compared it to white one (Table 1) and the influence of extract different the fruits on both plants in $S$. epidermidis higher than in the other type.

TABLE 1. Antibacterial influence (mean of inhibition zone diameter, $\mathbf{m m} \pm \mathbf{s d}$ ) of wild myrtle extracts fruits of 4 concentration for each one, $n=9$.

\begin{tabular}{|c|c|c|c|c|c|}
\hline plant & Bacteria & Conc\% $\%$ & Acetone & Ethanol & Water \\
\hline \multirow{8}{*}{ White } & \multirow{4}{*}{ S. aureus } & 100 & $23.00 \pm 0.00^{\mathrm{a}}$ & $22.33 \pm 0.50^{\mathrm{a}}$ & $18.00 \pm 0.00^{\mathrm{a}}$ \\
\hline & & 75 & $22.67 \pm 0.50^{\mathrm{b}}$ & $21.67 \pm 1.00^{\mathrm{a}}$ & $18.00 \pm 0.00^{\mathrm{a}}$ \\
\hline & & 50 & $19.00 \pm 0.00^{\mathrm{c}}$ & $18.00 \pm 0.00^{\mathrm{b}}$ & $16.33 \pm 0.50^{b}$ \\
\hline & & 25 & $16.00 \pm 0.00^{\mathrm{d}}$ & $18.00 \pm 0.00^{b}$ & $14.00 \pm 0.00^{\mathrm{c}}$ \\
\hline & \multirow{4}{*}{ S. epidermidis } & 100 & $22.00 \pm 0.00^{\mathrm{a}}$ & $32.11 \pm 2.42^{\mathrm{a}}$ & $20.89 \pm 1.69^{\mathrm{a}}$ \\
\hline & & 75 & $21.67 \pm 0.50^{\mathrm{b}}$ & $23.00 \pm 0.87^{b}$ & $16.44 \pm 0.73^{b}$ \\
\hline & & 50 & $20.00 \pm 0.00^{\mathrm{c}}$ & $18.67 \pm 0.50^{c}$ & $15.00 \pm 0.00^{\mathrm{c}}$ \\
\hline & & 25 & $18.00 \pm 0.00^{\mathrm{d}}$ & $18.00 \pm 0.00^{\mathrm{c}}$ & $12.78 \pm 0.67^{\mathrm{d}}$ \\
\hline \multirow{8}{*}{ Blue } & \multirow{4}{*}{ S. aureus } & 100 & $27.11 \pm 0.78^{\mathrm{a}}$ & $23.00 \pm 0.87^{\mathrm{a}}$ & $20.11 \pm 0.33^{\mathrm{a}}$ \\
\hline & & 75 & $27.11 \pm 0.78^{\mathrm{a}}$ & $19.33 \pm 1.00^{b}$ & $20.00 \pm 0.00^{\mathrm{a}}$ \\
\hline & & 50 & $21.78 \pm 0.44^{\mathrm{b}}$ & $18.00 \pm 0.00^{\mathrm{c}}$ & $16.00 \pm 0.00^{b}$ \\
\hline & & 25 & $14.89 \pm 0.60^{\mathrm{c}}$ & $12.00 \pm 0.00^{\mathrm{d}}$ & $12.00 \pm 0.00^{\mathrm{c}}$ \\
\hline & \multirow{4}{*}{ S. epidermidis } & 100 & $24.11 \pm 0.33^{\mathrm{a}}$ & $27.33 \pm 0.50^{\mathrm{a}}$ & $28.67 \pm 1.00^{\mathrm{a}}$ \\
\hline & & 75 & $24.11 \pm 0.33^{\mathrm{a}}$ & $23.44 \pm 1.13^{b}$ & $20.00 \pm 1.50^{\mathrm{b}}$ \\
\hline & & 50 & $16.89 \pm 0.60^{b}$ & $20.00 \pm 0.00^{\mathrm{c}}$ & $15.00 \pm 0.00^{\mathrm{c}}$ \\
\hline & & 25 & $14.78 \pm 0.44^{\mathrm{c}}$ & $17.00 \pm 1.50^{\mathrm{d}}$ & $11.00 \pm 0.00^{\mathrm{d}}$ \\
\hline
\end{tabular}

The different letters in the same column for a species indicate that the means difference is significant at level $\alpha=0.05$

\section{Antibacterial activity of extracts of myrtle leaves}

The influence of acetone extract of leaves of the white myrtle at the concentration of $100 \%$ reached $22.56 \mathrm{~mm}$ in $S$. aureus and $25 \mathrm{~mm}$ in $S$. epidermidis (Table 2). Acetone and ethanolic extracts of leaves of blue myrtle were effected one more the two tested bacteria than the white leaves (Table 2). Results also revealed that acetone and ethanolic extracts of leaves of blue and white with $S$. epidermidis was higher than in the other type (Table 2), and in contrast to the aqueous extract of leaves, white type was more influential on the two types of bacteria than blue type. The effect of aqueous extract of white leaves on $S$. aureus was higher than in the other type. Acetone and ethanolic extracts were more influential on $S$. epidermidis compared to aqueous extract. 
TABLE 2. Antibacterial influence (mean of inhibition zone diameter, $\mathbf{m m} \pm \mathrm{sd}$ ) of wild myrtle extracts leaves of $\mathbf{4}$ concentration for each one, $n=9$.

\begin{tabular}{|c|c|c|c|c|c|}
\hline Plant & Bacteria & Conc. $\%$ & Acetone & Ethanol & Water \\
\hline \multirow[t]{8}{*}{ White } & \multirow[t]{4}{*}{ S. aureus } & 100 & $22.56 \pm 0.73^{\mathrm{a}}$ & $22.33 \pm 0.50^{\mathrm{a}}$ & $23.22 \pm 0.83^{\mathrm{a}}$ \\
\hline & & 75 & $20.33 \pm 0.50^{\mathrm{b}}$ & $21.8 \pm 90.33^{\mathrm{b}}$ & $20.67 \pm 0.50^{b}$ \\
\hline & & 50 & $19.00 \pm 0.00^{c}$ & $21.00 \pm 0.00^{\mathrm{c}}$ & $20.00 \pm 0.00^{c}$ \\
\hline & & 25 & $18.00 \pm 0.00^{\mathrm{d}}$ & $20.00 \pm 0.00^{\mathrm{d}}$ & $16.00 \pm 0.00^{\mathrm{d}}$ \\
\hline & \multirow[t]{4}{*}{ S. epidermidis } & 100 & $25.00 \pm 0.70^{\mathrm{a}}$ & $25.00 \pm 0.00^{\mathrm{a}}$ & $18.67 \pm 1.00^{\mathrm{a}}$ \\
\hline & & 75 & $25.00 \pm 0.00^{\mathrm{a}}$ & $23.00 \pm 0.93^{\mathrm{b}}$ & $18.33 \pm 0.50^{\mathrm{a}}$ \\
\hline & & 50 & $25.00 \pm 0.00^{\mathrm{a}}$ & $23.00 \pm 0.00^{\mathrm{b}}$ & $18.00 \pm 0.00^{\mathrm{a}}$ \\
\hline & & 25 & $22.33 \pm 0.50^{b}$ & $23.00 \pm 0.00^{\mathrm{b}}$ & $13.67 \pm 0.50^{b}$ \\
\hline \multirow[t]{8}{*}{ Blue } & \multirow[t]{4}{*}{ S. aureus } & 100 & $25.67 \pm 0.50^{\mathrm{a}}$ & $25.33 \pm 0.50^{\mathrm{a}}$ & $21.33 \pm 0.50^{\mathrm{a}}$ \\
\hline & & 75 & $25.00 \pm 0.00^{\mathrm{a}}$ & $20.33 \pm 0.50^{b}$ & $16.00 \pm 0.00^{\mathrm{b}}$ \\
\hline & & 50 & $25.00 \pm 0.00^{\mathrm{a}}$ & $19.00 \pm 0.00^{\mathrm{c}}$ & $15.67 \pm 0.50^{b}$ \\
\hline & & 25 & $24.00 \pm 1.50^{\mathrm{b}}$ & $17.67 \pm 0.50^{\mathrm{d}}$ & $14.33 \pm 0.50^{\mathrm{c}}$ \\
\hline & \multirow[t]{4}{*}{ S. epidermidis } & 100 & $26.67 \pm 0.50^{\mathrm{a}}$ & $26.00 \pm 0.00^{\mathrm{a}}$ & $17.56 \pm 0.53^{\mathrm{a}}$ \\
\hline & & 75 & $25.00 \pm 0.00^{\mathrm{b}}$ & $21.78 \pm 0.44^{b}$ & $17.33 \pm 0.50^{\mathrm{a}}$ \\
\hline & & 50 & $25.00 \pm 0.00^{\mathrm{b}}$ & $20.00 \pm 0.00^{\mathrm{c}}$ & $16.00 \pm 0.00^{\mathrm{b}}$ \\
\hline & & 25 & $22.44 \pm 1.33^{\mathrm{c}}$ & $19.11 \pm 0.33^{\mathrm{d}}$ & $12.67 \pm 0.50^{\mathrm{c}}$ \\
\hline
\end{tabular}

The different letters in the same column for a species indicate that the means difference is significant at level $\alpha=0.05$.

Antibacterial activity of extracts of myrtle stems

Acetone and ethanolic extracts of myrtle stems of the white myrtle at the concentration of $100 \%$ was more influential than the blue type against the two tested bacteria and the effect of the two types of demodulator for both plants in $S$. epidermidis than in the other type (Table 3) and as in contrast to the effect of aqueous extract of stem of the two plants was more effective on S. aureus than in the other type.

TABLE 3. Antibacterial influence (mean of inhibition zone diameter, $\mathbf{m m} \pm \mathbf{s d}$ ) of wild myrtle extracts stems of 4 concentration for each one, $n=9$.

\begin{tabular}{|c|c|c|c|c|c|}
\hline Plant & Bacteria & Conc\% $\%$ & Acetone & Ethanol & Water \\
\hline \multirow[t]{8}{*}{ White } & \multirow[t]{4}{*}{ S. aureus } & 100 & $21.67 \pm 0.50^{\mathrm{a}}$ & $21.67 \pm 0.71^{\mathrm{a}}$ & $14.00 \pm 0.00^{\mathrm{a}}$ \\
\hline & & 75 & $21.33 \pm 0.50^{\mathrm{a}}$ & $19.67 \pm 0.50^{b}$ & $13.67 \pm 0.50^{\mathrm{a}}$ \\
\hline & & 50 & $20.00 \pm 0.00^{\mathrm{b}}$ & $19.33 \pm 0.50^{b}$ & $13.67 \pm 0.50^{\mathrm{a}}$ \\
\hline & & 25 & $20.00 \pm 0.00^{\mathrm{b}}$ & $18.58 \pm 1.24^{\mathrm{c}}$ & $8.33 \pm 0.50^{\mathrm{b}}$ \\
\hline & \multirow[t]{4}{*}{ S. epidermidis } & 100 & $29.67 \pm 3.08^{\mathrm{a}}$ & $23.22 \pm 1.64^{\mathrm{a}}$ & $13.0 \pm 0.87^{\mathrm{a}}$ \\
\hline & & 75 & $22.78 \pm 9.72^{b}$ & $21.00 \pm 0.00^{\mathrm{b}}$ & $11.67 \pm 0.50^{b}$ \\
\hline & & 50 & $21.00 \pm 0.00^{\mathrm{b}}$ & $20.33 \pm 0.50^{b}$ & $8.87 \pm 0.50^{\mathrm{c}}$ \\
\hline & & 25 & $21.00 \pm 0.00^{\mathrm{b}}$ & $16.00 \pm 0.00^{\mathrm{c}}$ & $7.67 \pm 0.50^{\mathrm{d}}$ \\
\hline \multirow[t]{8}{*}{ Blue } & \multirow[t]{4}{*}{ S. aureus } & 100 & $20.33 \pm 0.50^{\mathrm{a}}$ & $18.67 \pm 0.50^{\mathrm{a}}$ & $15.67 \pm 0.50^{\mathrm{a}}$ \\
\hline & & 75 & $18.00 \pm 0.00^{\mathrm{b}}$ & $18.33 \pm 0.50^{\mathrm{a}}$ & $15.33 \pm 0.50^{\mathrm{a}}$ \\
\hline & & 50 & $17.67 \pm 0.50^{b}$ & $17.67 \pm 0.50^{b}$ & $14.00 \pm 0.00^{\mathrm{b}}$ \\
\hline & & 25 & $17.00 \pm 0.00^{\mathrm{c}}$ & $13.00 \pm 0.00^{\mathrm{c}}$ & $9.67 \pm 0.50^{\mathrm{c}}$ \\
\hline & \multirow[t]{4}{*}{ S. epidermidis } & 100 & $23.00 \pm 0.00^{\mathrm{a}}$ & $20.78 \pm 0.83^{\mathrm{a}}$ & $12.33 \pm 0.50^{\mathrm{a}}$ \\
\hline & & 75 & $20.00 \pm 0.00^{\mathrm{b}}$ & $17.00 \pm 0.00^{\mathrm{b}}$ & $11.33 \pm 0.50^{\mathrm{b}}$ \\
\hline & & 50 & $18.67 \pm 1.00^{\mathrm{c}}$ & $16.33 \pm 0.50^{\mathrm{c}}$ & $11.33 \pm 0.50^{b}$ \\
\hline & & 25 & $14.00 \pm 0.00^{\mathrm{d}}$ & $14.00 \pm 0.00^{\mathrm{d}}$ & $8.00 \pm 0.00^{\mathrm{c}}$ \\
\hline
\end{tabular}

The different letters in the same column for a species indicate that the means difference is significant at level $\alpha=0.05$.

Egypt. J. Microbiol. 50 (2015) 


\section{Antibacterial activity of extracts of the roots}

Acetone and ethanolic extracts of the roots of blue myrtle were more influential on S. aureus, S. epidermidis than the roots extracts of white myrtle (Table 4). Results also revealed pronounced influence of acetone and ethanolic extracts as well as aqueous extract of the roots of blue myrtle on $S$. epidermidis were higher than on the other one.

TABLE 4. Antibacterial influence (mean of inhibition zone diameter, $\mathbf{m m} \pm$ sd) of wild myrtle extracts roots of 4 concentration for each one, $n=9$.

\begin{tabular}{|c|c|c|c|c|c|}
\hline Plant & Bacteria & Conc\% & Acetone & Ethanol & Water \\
\hline \multirow[t]{8}{*}{ White } & \multirow[t]{4}{*}{ S. aureus } & 100 & $15.67 \pm 0.50^{\mathrm{a}}$ & $15.00 \pm 0.00^{\mathrm{a}}$ & $22.00 \pm 0.00^{\mathrm{a}}$ \\
\hline & & 75 & $15.00 \pm 0.00^{\mathrm{b}}$ & $11.33 \pm 0.50^{\mathrm{b}}$ & $14.33 \pm 0.50^{\mathrm{b}}$ \\
\hline & & 50 & $15.00 \pm 0.00^{\mathrm{b}}$ & $10.00 \pm 0.00^{\mathrm{c}}$ & $13.33 \pm 0.50^{\mathrm{c}}$ \\
\hline & & 25 & $11.67 \pm 0.50^{\mathrm{c}}$ & $8.33 \pm 0.50^{\mathrm{d}}$ & $10.67 \pm 0.50^{\mathrm{d}}$ \\
\hline & \multirow[t]{4}{*}{ S. epidermidis } & 100 & $20.00 \pm 0.00^{\mathrm{a}}$ & $19.33 \pm 1.00^{\mathrm{a}}$ & $27.67 \pm 0.50^{\mathrm{a}}$ \\
\hline & & 75 & $18.67 \pm 0.50^{\mathrm{b}}$ & $19.33 \pm 1.00^{\mathrm{a}}$ & $26.33 \pm 0.50^{b}$ \\
\hline & & 50 & $15.33 \pm 1.00^{c}$ & $18.00 \pm 0.00^{\mathrm{b}}$ & $25.00 \pm 0.00^{\mathrm{c}}$ \\
\hline & & 25 & $12.78 \pm 0.97^{\mathrm{d}}$ & $16.00 \pm 0.87^{\mathrm{c}}$ & $15.00 \pm 0.87^{\mathrm{d}}$ \\
\hline \multirow[t]{8}{*}{ Blue } & \multirow[t]{4}{*}{ S. aureus } & 100 & $26.44 \pm 2.24^{\mathrm{a}}$ & $25.00 \pm 0.00^{\mathrm{a}}$ & $24.00 \pm 0.00^{\mathrm{a}}$ \\
\hline & & 75 & $17.67 \pm 0.50^{\mathrm{b}}$ & $17.67 \pm 0.50^{\mathrm{b}}$ & $24.00 \pm 0.00^{\mathrm{a}}$ \\
\hline & & 50 & $13.33 \pm 0.50^{\mathrm{c}}$ & $17.67 \pm 0.50^{b}$ & $15.67 \pm 1.00^{\mathrm{b}}$ \\
\hline & & 25 & $12.33 \pm 0.50^{c}$ & $11.33 \pm 0.50^{\mathrm{c}}$ & $11.67 \pm 0.50^{\mathrm{c}}$ \\
\hline & \multirow[t]{4}{*}{ S. epidermidis } & 100 & $35.00 \pm 0.00^{\mathrm{a}}$ & $32.33 \pm 2.00^{\mathrm{a}}$ & $27.33 \pm 0.50^{\mathrm{a}}$ \\
\hline & & 75 & $27.00 \pm 0.86^{\mathrm{b}}$ & $24.33 \pm 1.00^{\mathrm{b}}$ & $26.67 \pm 1.00^{\mathrm{a}}$ \\
\hline & & 50 & $24.00 \pm 0.86^{\mathrm{c}}$ & $21.33 \pm 1.32^{\mathrm{c}}$ & $24.33 \pm 0.50^{b}$ \\
\hline & & 25 & $23.00 \pm 0.00^{\mathrm{d}}$ & $18.00 \pm 0.00^{\mathrm{d}}$ & $22.67 \pm 0.50^{\mathrm{c}}$ \\
\hline
\end{tabular}

The different letters in the same column for a species indicate that the means difference is significant at level $\alpha=0.05$

Table 5 shows antibacterial activity of extract parts of the two types of myrtle plants against bacteria. Effectiveness of extracts could be arranged as follows: leaves $>$ fruits $>$ stem $>$ roots. Increasing concentration increased inhibition of bacterial growth and results showed that acetone extracts were more effectiveness against the two types of bacteria, followed by ethanolic then aqueous extracts. The effective action against $S$. epidermidis was more better than on $S$. aureus. Generally, the effect of parts of myrtle blue extracts were more effective aganist bacteria than white. Comparing the effect of extracts of wild myrtle white and blue on the tested bacteria. The obtained results revealed that extracts of blue type were more effective against $S$. epidermidis than S. aureus. Similar results were reported by Layqa et al. (2014).

Gram-negative bacteria cause substantially prevention for penetration of oil and avoid the accumulation of essential oils in the membrane of the target cell (Bezic et al., 2003). These Gram-positive bacteria (Staphylococcus aureus) are more sensitive to myrtle extracts, in myrtle leaves presence of different polyphenolic compounds (Romani et al., 1999). Hypothesis seems to be anti-bacteria linked to the presence of phenolic installation that affect the cellular membranes (Cakir et al., 2004). The combined effect will be on the cells and wall and permeability, as well as to interfere with the functions of the membrane as carrier electron and enzymatic effectiveness or transportation of nutrients (Fung et al., 1977 and Bajpai et al., 2008), which leads ultimately to influence the bacteria. 
TABLE 5. Comparison of the inhibition zone diameter (mean in $\mathbf{m m} \pm$ sd) of myrtle extract of leaves, fruits, stem and root on S. aureus, S. epidermidis.

\begin{tabular}{|c|c|c|c|c|c|}
\hline \multirow{2}{*}{$\begin{array}{l}\text { Bacteria } \\
\text { Extract }\end{array}$} & \multirow{2}{*}{$\begin{array}{c}\text { Variable } \\
\text { Concentration } \\
\%\end{array}$} & \multicolumn{2}{|c|}{ S. aureus } & \multicolumn{2}{|c|}{ S. epidermidis } \\
\hline & & White & Blue & White & Blue \\
\hline \multirow{4}{*}{ Leaves } & 25 & E $20.00 \pm 0.00$ & A $24.00 \pm 1.50$ & E $23.00 \pm 0.00$ & A $22.44 \pm 1.33$ \\
\hline & 50 & E $21.00 \pm 0.00$ & A $25.00 \pm 0.00$ & A $25.00 \pm 0.00$ & A $25.00 \pm 0.00$ \\
\hline & 75 & E $21.8 \pm 90.33$ & A $25.00 \pm 0.00$ & A $25.00 \pm 0.00$ & A $25.00 \pm 0.00$ \\
\hline & 100 & W $23.22 \pm 0.83$ & A $25.67 \pm 0.50$ & $\begin{array}{c}\mathrm{A}, \mathrm{E} \\
25.00 \pm 0.70\end{array}$ & A $26.67 \pm 0.50$ \\
\hline \multirow{4}{*}{ Fruits } & 25 & E $18.00 \pm 0.00$ & A $14.89 \pm 0.60$ & A,E $18.00 \pm 0.00$ & E $17.00 \pm 1.50$ \\
\hline & 50 & A $19.00 \pm 0.00$ & A $21.78 \pm 0.44$ & A $20.00 \pm 0.00$ & E $20.00 \pm 0.00$ \\
\hline & 75 & A $22.67 \pm 0.50$ & A $27.11 \pm 0.78$ & E $23.00 \pm 0.87$ & A $24.11 \pm 0.33$ \\
\hline & 100 & A $23.00 \pm 0.00$ & A $27.11 \pm 0.78$ & E $32.11 \pm 2.42$ & W $28.67 \pm 1.00$ \\
\hline \multirow{4}{*}{ Stem } & 25 & A $20.00 \pm 0.00$ & A $17.00 \pm 0.00$ & A $21.00 \pm 0.00$ & $\mathrm{~A}, \mathrm{E} 14.00 \pm 0.00$ \\
\hline & 50 & A $20.00 \pm 0.00$ & A,E $17.67 \pm 0.50$ & A $21.00 \pm 0.00$ & A $18.67 \pm 1.00$ \\
\hline & 75 & A $21.33 \pm 0.50$ & E $18.33 \pm 0.50$ & A $22.78 \pm 9.72$ & A $20.00 \pm 0.00$ \\
\hline & 100 & A,E $21.67 \pm 0.71$ & A $20.33 \pm 0.50$ & A $29.67 \pm 3.08$ & A $23.00 \pm 0.00$ \\
\hline \multirow{4}{*}{ Root } & 25 & A $11.67 \pm 0.50$ & A $12.33 \pm 0.50$ & E $16.00 \pm 0.87$ & A $23.00 \pm 0.00$ \\
\hline & 50 & A $15.00 \pm 0.00$ & E $17.67 \pm 0.50$ & W $25.00 \pm 0.00$ & W 24.33 \pm 0.50 \\
\hline & 75 & A $15.00 \pm 0.00$ & A,E $17.67 \pm 0.50$ & W $26.33 \pm 0.50$ & A $27.00 \pm 0.86$ \\
\hline & 100 & $\mathrm{~W} 22.00 \pm 0.00$ & A $26.44 \pm 2.24$ & W 27.67 \pm 0.50 & A $35.00 \pm 0.00$ \\
\hline
\end{tabular}

A: Acetone, E: Ethanol, W: Water

The different means in the same column for a species indicate that the means difference is significant at level $\mathrm{p}<0.05$.

It could be concluded that the extracts of myrtle plants are effective in principle as an antibacterial agents, it has been reported that ethanol extract of myrtle possess antibacterial effect against $S$. aureus (Salvagnini et al., 2008). The ability of plants to synthesize aromatic substances and secondary metabolites has been of importance in drugs development (Cowan, 1999), Some of the most important compounds of plants with medicinal uses are: alkaloids, tannins, flavonoids, sterols and phenols (Edeoga et al., 2005). These compounds can be extracted from plants by use of different solvents ranging from alcohols, chloroform, ether, hexane and water (Cowan, 1999). The dried leaves of these herbs contain terpineolene, cineol, linalool, terpineole, linalyl acetate, tannins and flavonoids compounds and there were numerous reports about the anti-parasitic and anti-infective properties of the extract of these herbs (Rahim et al. and 1998, Garg \& Denger, 1998).

\section{Recommendation}

Enhance preparedness for response to emerging diseases contributing to the development of national drugs and therapeutic goods legislation. 


\section{References}

Al-Salammi, A. (2006) Study of effect of extracts of Myrtus communis L. and Allium sativum L. on Pseudomonas aeruginosa in vitro and in vivo. University of Kufa in partial fulfillment of the requirments for the Degree of Master of Science in Biology Microbiology.

Amensour, M., Bouhdid, S. and Fernandez-Lopez, J. (2010) Antibacterial activity of extracts of Myrtus communis against food-borne pathogenic and spoilage bacteria. Int. J.Food Proper, 13, 1215-1224.

Ammara, H., Salma, R., Farah, D. and Shahid, M. (2009) Antimicrobial activity of some plant extracts having hepatoprotective effects. Journal of Medicinal Plant Research, 3(1), 20-23.

Andrews, J. (2003) "BSAC Disc Diffusion Method for Antimicrobial Susceptibility Testing”. (Version, 2.1.4). pp. 1-51.

Archer, N. K., Mazaitis, M., Costerton, J., Leid, J., Powers, M. and Shirtliff, M. (2011) Staphylococcus aureus biofilms: properties, regulation, and roles in human disease. Virulence, 2, 445- 459.

Bajpai, V.K., Rahman, A. and Kang, S. (2008) Chemical composition and inhibitory parameters of essential oil and extracts of Nandina domestica Thunb to control foodborne pathogenic and spoilage bacteria. International Journal of Food Microbiology, 125 (2), 117-122.

Barretti, P., Moraes, T.M., Camargo, C.H., Caramori, J.C., Mondelli, A.L., Montelli, A.C. and da Cunha, M.L. (2012) Peritoneal dialysis-related peritonitis due to Staphylococcus aureus: A single-center experience over 15 years. Plos One, 7, e31780.

Bezic, N., Skocibusic, M., Dinkic, V. and Radonic, A. (2003) Composition and antimicrobial activity of Achillea clavennae L. essential oil. Phytother. Res. 17, 10371040 .

Bouzouita, N., Kachouri, F., Hamid, M. and Chaabouni, M. (2003) Antimicrobial activity of essential oils from Tunisian aromatic plants. Flavour Fragrance J. 18(5), 380-383.

Cakir, A., Kordali, S., Zengin, H., Izumi, S. and Hirata, T. (2004) Composition and antifungal activity of essential oils isolated from Hypericum hyssopifolium and Hypericum heterophyllum. Flavour \& Fragrance J. 19, 62-68.

Chambers, H.F. (2001) The changing epidemiology of Staphylococcus aureus. Emerg Infect Dis. 7,178-82.

Cowan, M. M. (1999) Plant products as antimicrobial agents. Clinical Microbiology Reviews, 12, 564-582. 
De Laurentis, N., Rosato, A., Gallo, L., Leone L. and Milillo M. (2005) Chemical composition and antimicrobial activity of Myrtus communis. Rivista Italiana EPPOS, 39, 3-8.

Dugler, B. and Gonuz, A. (2004) Antimicrobial activity of certain plants in Turkish traditional medicine. Asian J. of plant Sciences, 3(3), 104-107.

Edeoga, H.O., Okwu, D. and Mbabie, B. (2005) Phytochemical constituents of some Nigerian medicinal plants. African Journal of Biotechnology ,4, 685-688.

Fung, D. C., Taylor, S. and Kahan, J. (1977) Effects of butylated hydroxyanisole (BHA) and Butylated hydroxytoluene (BHT) on growth and aflatoxin production of Aspergillus flavus. Journal of Food Safety, 1, 39-51.

Garg, S.C. and Denger, S.L. (1998) Antifungal activity of the essential oil of Myrtus communis var. microphylla. Herba Hungarica , 27(2-3), 123-124.

Gupta, M. P., Solis, P., Calderon, A., Guinneau - Sinclair, F. and Correa, M. (2005) Medical ethnobotany of the tribes of Bocas del Toro, Panama J. of Ethnopharmacology, 96, 389-401.

Harikrishnan, R., Nisha, R. and Balasundaram, C. (2003) Hematological and biochemical parameters in common carp, Cyprinus carpio, following herbal treatment for Aeromonas hydrophila infection. Aquaculture, 221(1-4), 41-50.

Haussen, A. D. and Rand, J. (1998) Evaluation and treatment of infection at the site of a total hip or knee arthroplasty. J. Bone Joint Surg, 80-A, 910-22.

Hope, P. G., Kristinson, K., Norman, P. and Elson, R. (1989) Deep infection of cemented total hip arthroplasties caused by coagulase-negative Staphylococci. J. Bone Joint Surg [Br],71-B, 851-855.

Horstkotte, M.A., Knobloch, J. K. M., Rohade H., Dobinsky, S. and Mack, D. (2004) Evaluation of the BD Phoenix automated microbiology system for detection of metgicillin resistance in coagulase-negative Staphylococci, Journal of Clinical Microbiology, 42(11), 5041-5046.

Idu, M., Omogbai, E., Aghimien, G., Amaechina, F., Timothy, O. and Omonigho, S. (2007) Preliminary phytochemistry, antimicrobial properties and acute toxicity of Stachytarpheta jamaicensis (L.) Vahl. Leaves. Trends in Medical Research, 2,193198.

Immanuel, G., Vincybai,V. C. and Sivaram, V. (2004) Effect of butanolic extracts from terrestrial herbs and seaweeds on the survival, growth and pathogen (Vibrio parahaemolyticus) load on shrimp Penaeus indicus juveniles. Aquaculture, 236(1-4), 53-65.

Iwu, M. W., Duncan, D. and Okunji, C. (1999) New antimicrobials of plant origin. In: "Perspective on New Crops and New Uses". Janick, J. (Ed.) pp.107-108 ASHS Press. Alexandria, VA. 
Kuete, V. (2010) Potential of cameroonian plants and derived products against microbial infections: A review. Planta Med, 13,1-13. doi: 10.1055/s-0029-1240671.

Layqa, M., Ali Nizam, A. and Alqadi, I. (2014) Activity of different parts extractions of cultured myrtle against some pathogenic bacteria. Damascus University Journal for Basic Sciences, ISSN 1726-5487.

Malicova, L., Sedl, A. I., Novacova, D. and Nemec, M. (2007) Ribotyping and biotyping of Staphylococcus epidermidis isolated from hospital environment. Folia Microbiol, (Praha), 52(4), 375-80.

Maneemegalai, S. and Naveen, T. (2010) Evaluation of antibacterial activity of flower extracts of Cassia auriculata. Ethnobotanical Leaflets, 14, 8-20.

Nascimento, G., Locatelli, J., Freitas, P. and Silva, G. (2000) Antibacterial activity of plant extracts and phytochemicals on antibiotic-resistant bacteria. Braz. J. Microbiol. 31(1), 247-56.

Otto, M. (2008) Staphylococcal biofilms. Curr. Top. Microbiol. Immunol. 322, 207-228.

Shahidi-Bonjar, G. H. (2004-a) Antibacterial screening of plants used in Iranian folkloric medicine. Fitoterapi, 75, 231-235.

Shahidi-Bonjar, G.H. (2004-b) Screening for antibacterial properties of some Iranian plants against two strains of Escherichia coli. Asian J. Plant Sci. 3(3), 310-314.

Mansouri, S., Formoudi, A., Ghaneie, T. and Najar, A. (2001) Antibacterial activity of the crude extracts and fractionated consitutuents of Myrtus communis. Pharm, Biol., 39, 399-401.

Parekh, J. and Chanda, S. (2007) Antibacterial and phytochemical studies on twelve species of Indian medicinal plants. Afric. J. Biomed. Res. 10,175-181.

Rahim, Z., Sanyal, S.C. and Aziz, K.M. (1998) Isolation of enterotoxigenic, haemolytic and antibiotic resistant Aermonas hydrophila strains from infected fish in Bangladesh. Appl. Environ. Microbiol. 48(4), 865-867.

Rahimi, M. and Athari, A. (2008) "Translation of Jawets Medical Microbiology". Gorge Federic Broxe. 24 ${ }^{\text {th }}$ ed. pp.320-403. Tehran: Aeedj Press,

Rios, J.L. and Recio, M.C. (2005) Medicinal plants and antimicrobial activity. $J$. Ethnopharmacol. 13, 80-84.

Rojas, R., Bustamante, B., Bauer, J., Fernandez, I., Alban, J. and Locka, O. (2003) Antimicrobial activity of selected Peruvian medicinal plants . Journal of Ethnopharmacology, 88,199-204.

Romani, M., Marchi, J., Banelli, B. and Casciano, I. (1999) Identification and quantitation of polyphenols in leaves of Myrtus communis L. Chromatographia, 49, $17-20$. 
Sakagami, Y. and Kajimura, K. (2002) Bactericidal activities of disinfectants against vancomycin-resistant Enterococci. J. Hosp. Infec. 50(2),140-4.

Salvagnini, L. E., Oliveira, J. and Dos-Santos, L. (2008) Antibacteriana de folhas de Myrtus communis L. (Myrtaceae)] Spanish [Abstract]. Brazilian J. Pharmaconosy, 18(2), 241-244.

Sandhu, D. S. and Heinrich, M. (2005) The use of health foods, spices and other botanicals in the sikh community in London, Phytotherapy Research, 19, 633-642.

Mansouri, S., Foroumadi, A., Ghaneie, T. and Najar, A. (2001) Pharm. Biol, 39, 399-401.

Shanmugavelu, S., Ruzickova, G., Zrustova, J. and Brooker, J. D. (2006) A fermentation assay to evaluate the effectiveness of antimicrobial agents on gut microflora, J. Microbiol Methods, 67(1), 93-101.

Sharifi , A., Naghmachi, M. and Bahrami, S. (2010) Antimicrobial activities of Dorema auchri. Armaghane-Danesh, 15(4), 378-386.

StatSoft, Inc. (2007) STATISTICA for Windows [Computer program manual]. Tulsa, OK: StatSoft, Inc., 2300 East $14^{\text {th }}$ Street, Tulsa, OK 74104.

Vaghasiya, Y. and Chanda, S. V. (2007) Screening of methanol and acetone extracts of fourteen indian medicinal plants for antimicrobial activity. Turk. J. Biol. 31, 243-248.

Walton, D., Shields, A., Reece, K., Bittner, T., Frye, S., Renwick, A., Shah, K., $\quad$ and Healy, M. (2004) Comparison of Coagulase-Negative Staphylococcus Species Identification using Automated Rep-PCR and sodA Sequencing. Bacterial Barcodes (Spectral Genomics, Inc.), Houston, TX, USA. Poster \# C-004, American Society for Microbiology.

Wieser, M. and Busse, H. (2000) Rapid identification of Staphylococcus epidermidis. Int. J. Syst. Evol. Microbiol.50, 1087- 1093.

Ziel, C.O. (2004) Comparison of coagulase-negative staphylococcus species identification using automated Rep-PCR and soda Sequencing . American Society for Microbiology, New Orleans, LA, USA, May pp. 23-27. 


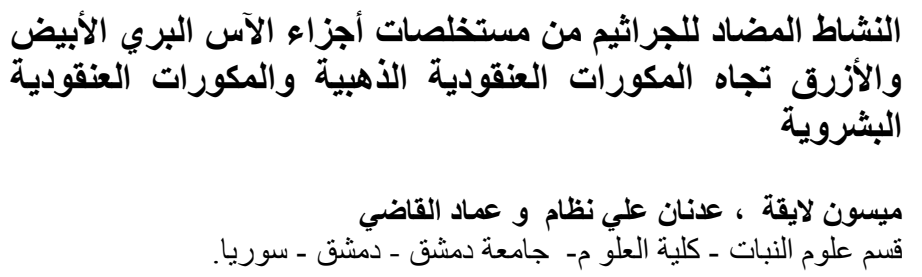

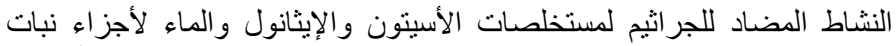
الآس البري .Myrtus communis L في سوريا (الجذر، الساق، الأوراق،

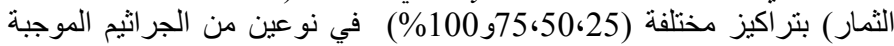

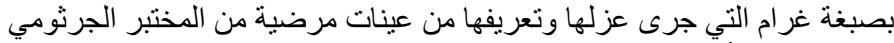

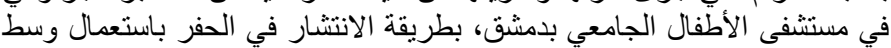

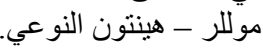

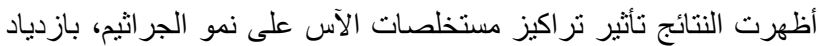

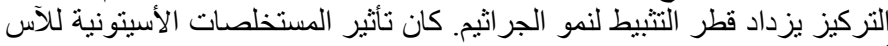

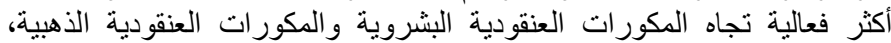

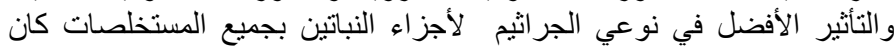

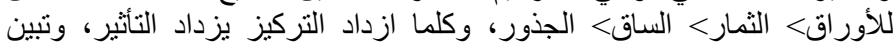

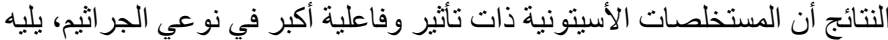

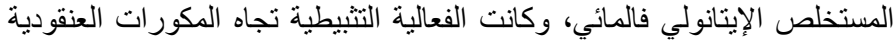

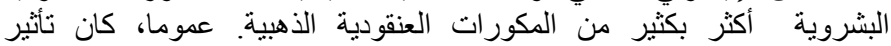
مستخلصات أجزاء الآس الأزرق أكثر فعالية على الجر اثثبم من النوع الأبيضة أبيض. هذه الدر اسة تؤكد قدرة النباتات المضادة للجر اثثم وفائدتها في علاج الكائنات الحية الدقيقة الايجابية الغرام المقاومة. 